\title{
Relationship between Emotional Intelligence and Geography Learning Outcomes of Class XII Students at Wahdah Islamiyah Integrated Islamic High School Makassar
}

\author{
Ibrahim Abbas ${ }^{1}$, Erman Syarif ${ }^{2}$, Lisman $^{3}$ \\ ${ }^{123}$ JURUSAN GEOGRAFI / FAKULTAS MATEMATIKA DAN ILMU PENGETAHUAN \\ ALAM / UNIVERSITAS NEGERI MAKASSAR
}

Email : $\underline{\text { ibrahimabbas@unm.ac.id }{ }^{1} \text {,ermansyarif@unm.ac.id }{ }^{2}, \text { lisman@gmail.com }^{3}}$

(Received: Agu/2021; Reviewed: Sept/2021; Accepted: Sept/2021; Published: Okt/2021) penulis (https://creativecommons.org/licenses/by-nc/4.0/ ).

\begin{abstract}
This study aims to determine whether there is a relationship between emotional intelligence and geography learning outcomes in class XII Islamic Senior High School Wahdah Islamiyah Makassar. This research is a type of quantitative research with the Spearman Rank correlation method. The data collection technique uses a questionnaire. The sampling technique in this study used a saturated sampling technique with a total of 25 respondents. For learning outcomes data is taken from the grade XII student report cards in the geography subject. The results of the analysis of emotional intelligence data are included in the medium category with an average value $=107.84$ at intervals 103-110, for geography learning outcomes are included in the low category with an average value $=83.52$ at intervals $81-84$, to prove whether or not there is a relationship between emotional intelligence and geography learning outcomes, it can be seen from the calculation obtained using the Spearman Rank correlation formula, where the value of $r s=0.037$, with a significant value of 0.861 . Because sig $>0.05$, it can be concluded that emotional intelligence does not have a significant relationship with geography learning outcomes and the relationship is included in the very low category.
\end{abstract}

Keywords: Emotional Intelligence; Geography Learning Outcomes

\section{ABSTRAK}

Penelitian ini bertujuan untuk mengetahui apakah ada hubungan kecerdasan emosional dengan hasil belajar geografi di kelas XII SMA Islam Terpadu Wahdah Islamiyah Makassar. Penelitian ini merupakan jenis penelitian kuantitatif dengan metode korelasi Rank Spearman. Adapun teknik pengumpulan data menggunakan angket. Teknik pengambilan sampel dalam Penelitian menggunakan teknik sampling jenuh dengan jumlah responden sebanyak 25 orang. Untuk data hasil belajar diambil dari nilai rapor peserta didik kelas XII pada mata pelajaran geografi. Hasil analisis data kecerdasan emosional termasuk dalam kategori sedang dengan nilai rata-rata $=107,84$ pada interval 103-110, untuk hasil 
Ibrahim Abbas, Erman Syarif, Lisman, 2021, Hubungan Kecerdasan Emosional Dengan Hasil Belajar Geografi Siswa Kelas XII di SMA Islam Terpadu Wahdah Islamiyah Makassar

belajar geografi termasuk ke dalam kategori rendah dengan nilai rata-rata $=$ 83,52 pada interval 81-84, untuk membuktikan ada atau tidak hubungan kecerdasan emosional dengan hasil belajar geografi maka dapat dilihat dari perolehan perhitungan dengan menggunakan rumus korelasi Rank Spearman, dimana nilai $r s=0,037$, dengan nilai signifikan 0,861. Karena sig >0,05, dapat disimpulkan bahwa kecerdasan emosional tidak memiliki hubungan yang signifikan terhadap hasil belajar geogarfi dan hubungan tersebut termasuk ke dalam kategori sangat rendah.

Kata Kunci: Kecerdasan Emosional; Hasil Belajar Geografi

\section{PENDAHULUAN}

Pendidikan adalah usaha sadar dan terencana untuk mewujudkan suasana belajar dan proses pembelajaran agar peserta didik secara aktif dapat mengembangkan potensi dirinya untuk memiliki kekuatan spiritual keagamaan, pengendalian diri, kepribadian, kecerdasan, akhlak mulia, serta keterampilan yang diperlukan dirinya, masyarakat, bangsa dan negara. Demikianlah pengertian pendidikan menurut Undang-Undang No. 20 Tahun 2003 Tentang Sistem Pendidikan Nasional.

Alinea keempat Pembukaan Undang-Undang Dasar Negara Republik Indonesia Tahun 1945 menegaskan bahwa salah satu tujuan pembentukan Pemerintah Negara Indonesia adalah mencerdaskan kehidupan bangsa. Oleh karena itu, pendidikan harus dipahami sebagai bagian yang tidak terpisahkan dari upaya pembentukan Negara Indonesia. Pendidikan merupakan elemen dasar dari pembangunan nasional yang mampu menghantarkan kesejahteraan bagi rakyat Indonesia. Untuk mewujudkan suatu Bangsa yang maju dan beradab, maka masyarakat diharapkan dapat mengetahui arti pentingnya pendidikan kelak untuk kehidupan mereka ke depan. Peran pendidikan di Indonesia dimaksudkan untuk menjadikan peserta didik yang memiliki potensi, kekuatan spiritual, kepribadian, emosional dan kecerdasan.

Dalam dunia pendidikan kita selalu berorientasi pada intelektual, akan tetapi disisi lain mengesampingkan pengembangan sikap atau nilai dan perilaku dalam pembelajarannya. Kurikulum pendidikan kita saat ini lebih menekankan pada pengembangan intelektual peserta didik, dan masyarakat kita pada umumnya beranggapan bahwa hanya dengan kecerdasan intelektual seorang anak mampu menghadapi tantangan era globalisasi. Hal tersebut menyebabkan penerapan Kurikulum 2013 yang diselenggarakan dinilai belum maksimal (Duhita et al., 2020). Pengetahuan tidak dapat dipindahkan dari pikiran guru ke peserta didik, namun dibangun oleh peserta didik sendiri melalui pengalaman nyata (Ibrahim, 2015).

Kecerdasan emosional adalah suatu kecerdasan sosial yang berhubungan dengan kemampuan seseorang dalam mengenal dan membedakan emosi baik dalam dirinya maupun emosi dalam diri orang lain yang dimana kemampuan tersebut digunakan agar mengatur pola pikir dan prilakunya. (Bariyyah \& Latifah, 2019). Peserta didik yang memiliki hasil belajar yang baik maka memiliki kecerdasan emosional yang baik pula (Indriawati, 2018) karena peserta didik yang memiliki kecerdasan emosional mampu mengekspresikan emosi untuk selalu bersikap dan bertindak efektif, memotivasi dirinya, disiplin dan mampu mengontrol diri dalam situasi sulit. Apabila peserta didik tidak memiliki kecerdasan emosional yang baik maka 
Ibrahim Abbas, Erman Syarif, Lisman, 2021, Hubungan Kecerdasan Emosional Dengan Hasil Belajar Geografi Siswa Kelas XII di SMA Islam Terpadu Wahdah Islamiyah Makassar

bersikap dan bertindak diluar pemikirannya dan biasanya ketika keinginan tidak tercapai maka dapat merubah sikapnya menjadi negasi dari sikap sebelumnya hal ini terjadi karena anak tersebut tidak dapat mengelola dengan baik emosinya..

Intelegensi bukanlah merupakan satu-satunya kunci keberhasilan seseorang, akan tetapi ada faktor lain yang mempengaruhinya. Menurut (Goleman, 2000) yang menyatakan bahwa kecerdasan intelektual hanya berpengaruh sebanyak $20 \%$ terhadap keberhasilan hidup seseorang sedangkan $80 \%$ dipengaruhi oleh kecerdasan emosional atau emotional intelligence yakni kemampuan memotivasi diri, mengatasi datangnya frustasi, mampu mengontrol tekanan hati, mengatur mood, berempati serta kemampuan dalam bekerja sama.

Dalam penelitian yang dilakukan oleh tim peneliti American Psychological Association (APA) yang mengukur tingkat kecerdasan emosional peserta didik dan mengaitkannya dengan nilai ujian. Data yang dianalisis didapatkan dari 160 studi mulai dari tahun 1998 sampai dengan 2019 yang melibatkan lebih dari 42.000 peserta didik di 27 negara (76\% berbahasa Inggris). Adapun kirteria peserta didik yang diteliti mulai dari usia sekolah dasar sampai jenjang perguruan tinggi. Hasil penelitian didapatkan bahwa peserta didik yang memiliki kecerdasan emosional yang baik cenderung mendapatkan nilai ujian yang lebih tinggi dan memiliki prestasi yang lebih baik dibangding dengan peserta didik dengan kecerdasan emosi yang rendah. Selain bermanfaat untuk meningkatkan prestasi belajar, peserta didik yang memiliki kecerdasan emosional yang baik dinilai mampu mengelola dunia sosial, seperti menjalin hubungan baik dengan guru, teman, dan keluarga. Kecerdasan emosional merupakan modal dasar untuk peserta didik demi menyongsong masa depan karena dengan kecerdasan emosional seseorang mampu menghadapi berbagai tantangan termasuk tantangan berhasil dalam akademik. Dengan adanya kecerdasan emosiona yang baik oleh peserta didik maka tidak akan terbebani ketika belajar dan tidak akan merasa cemas dalam menghadapi berbagai kesulitan.

Menurut (Sudjana, 2010) hasil belajar merupakan kemampuan- kemampuan yang didapatkan peserta didik setelah ia menerima pengalaman belajarnya. Hal ini sejalan dengan pendapat (Rifa, n.d.) menyatakan bahwa hasil belajar adalah perubahan perilaku peserta didik setelah melakukan kegiatan belajar. Penulis (Ahmadi, 2019) dalam bukunya menjelaskan tentang pengertian peserta didik adalah orang yang belum dewasa, yang memerlukan usaha, bantuan, bimbingan orang lain untuk menjadi dewasa, guna dapat melaksanakan tugasnya sebagai makhluk Tuhan, sebagai umat manusia, sebagai warga negara, sebagai anggota masyarakat dan sebagai suatu pribadi atau individu. Sedangkan (Nizar, 2002) menjelaskan bahwa peserta didik merupakan orang yang dikembangkan. Dengan demikian tujuan pembelajaran akan mencapai hasil yang maksimal apabila guru mampu memahami karakteristik peserta didik yang dimiliki baik menyangkut faktor biologis maupun faktor sosial psikologis.

Hasil sebuah survei terhadap orang tua dan guru membuktikan bahwa anak-anak generasi sekarang lebih sering mengalami masalah-masalah emosional dari pada generasi terdahulu. Rata-rata anak-anak sekarang tumbuh dalam kesepian dan depresi, lebih mudah marah dan lebih sulit diatur, lebih gugup, cenderung cemas, serta lebih impulsif dan agresif (Goleman, 2000). Menurut (Khalijah et al., 2021) bahwa perhatian orang tua yang rendah dapat mempengaruhi pencapaian hasil belajar yang cenderung kurang maksimal.

Istilah kecerdasan emosional dalam pendidikan, bagi sebagian orang mungkin dianggap sebagai jawaban atas kejanggalan tersebut. Teori Daniel Goleman, memberikan definisi baru terhadap kata cerdas. Walaupun EQ merupakan hal yang relatif baru dibandingkan IQ, namun beberapa penelitian telah mengisyaratkan bahwa kecerdasan emosional tidak kalah penting 
Ibrahim Abbas, Erman Syarif, Lisman, 2021, Hubungan Kecerdasan Emosional Dengan Hasil Belajar Geografi Siswa Kelas XII di SMA Islam Terpadu Wahdah Islamiyah Makassar

dengan IQ. Kecerdasan sebagai suatu kapasitas umum dari individu untuk bertindak, berpikir rasional dan berinteraksi dengan lingkungan secara efektif (Sagala, 2010). Sehingga dapat diartikan pula bahwa kecerdasan atau Intelligensi adalah kemampuan untuk menguasai kemampuan tertentu.

Keseimbangan antara kecerdasan intelektual dan kecerdasan emosional akan berpengaruh dalam kegiatan belajar jika ada minat dan motivasi yang tinggi dalam belajar, ketika rasional peserta didik dapat berfikir dengan baik, emosionalpun akan merespon baik pula. Dalam hal ini, ketika peserta didik memiliki minat dan motivasi dalam belajar serta dapat menyeimbangkan rasional atau pengetahuan dan emosionalnya, maka akan sangat berpengaruh pada hasil belajarnya. Hal ini sejalan dengan pernyataan Ary Ginanjar (2001) "kecerdasan emosional seseorang dapat meningkat dan terus ditingkatkan sepanjang kita hidup

Hal tersebut sejalan dengan yang dikatakan oleh (Hamalik, 2007) bahwa hasil belajar adalah sebagai proses terjadinya perubahan tingkah laku pada diri seseorang yang dapat diamati dan diukur bentuk pengetahuan, sikap dan keterampilan. Hasil belajar merupakan hasil maksimum yang sudah dicapai oleh peserta didik selama proses belajar mengajar dalam mempelajari suatu materi tertentu. Hal serupa diungkapkan oleh (Nyompa et al., 2018) bahwa untuk mengetahui hasil belajar siswa guru perlu mengadakan evaluasi atas kemampuan siswa saat memahami materi yang telah disampaikan.

Menurut (Syarif et al., 2020) bahwa peran guru yang menguasai materi pelajaran, model pembelajaran dan dapat menggunakan media pembelajaran yang tepat akan mempengaruhi hasil belajar yang maksimal. Hasil belajar tidak mutlak berupa nilai saja, akan tetapi dapat berupa perubahan atau peningkatan sikap, kebiasaan, pengetahuan, kedisiplinan, keuletan, keterampilan dan hal lain yang menuju kepada perubahan yang positif, misal dalam suatu mata pelajaran. Pengukuran hasil belajar dilakukan oleh guru biasanya dilakukan setiap mata pelajaran dan materi tertentu.

Pendekatan dalam melakukan pengukuran hasil belajar Geografi dapat dilakukan dengan berbagai metode. Menurut bahwa (Nurjannah et al., 2020) pembelajaran geografi merupakan sebuah pembelajaran yang bersifat naturalistic yang mengharuskan para peserta didik membuka cakrawala pengetahuan dengan memadukan pembelajaran di kelas maupun di alam. Pembelajaran geografi pada jenjang kelas XII bertujuan membekali peserta didik agar memiliki pemahaman mengenai pola spasial, lingkungan, dan kewilyahan serta menguasai keterampilan dasar dalam memperoleh data dan informasi sehingga mampu menumbuhkan perilaku peduli terhadap lingkungan hidup. Sehingga menguatkan bahwa penerapan Ilmu geografi di sekolah sangat penting mengingat pendekatan ilmunya mengarah lingkungan yang ada di sekitar kita (Hasriyanti, 2019).

Berdasarkan observasi penulis dalam proses belajar mengajar di SMA IT Wahdah Islamiyah sering ditemukan peserta didik yang tidak dapat meraih hasil belajar yang setara dengan kemampuan intelegensinya. Ada peserta didik yang mempunyai kemampuan intelegensi tinggi tetapi memperoleh hasil belajar yang relatif rendah, namun ada peserta didik yang walaupun kemampuan intelegensinya relatif rendah, dapat meraih hasil belajar yang relatif tinggi. Kecerdasan emosional merupakan salah satu faktor yang penting yang seharusnya dimiliki oleh peserta didik yang memiliki kebutuhan untuk meraih hasil belajar yang lebih baik di sekolah. 
Ibrahim Abbas, Erman Syarif, Lisman, 2021, Hubungan Kecerdasan Emosional Dengan Hasil Belajar Geografi Siswa Kelas XII di SMA Islam Terpadu Wahdah Islamiyah Makassar

Maka dari itu pada penelitian ini akan dikaji lebih mendalam terkait: "Hubungan Kecerdasan Emosional Dengan Hasil Belajar Geografi Kelas XII di SMA IT Wahdah Islamiyah Makassar"

\section{METODE}

Jenis penelitian yang digunakan pada penelitian ini adalah penelitian kuantitatif non eksperimen dengan pendekatan expost facto. (Arikunto, 2019) mendefinisikan penelitian korelasional sebagai penelitian yang dilakukan oleh peneliti untuk mengetahui tingkat hubungan

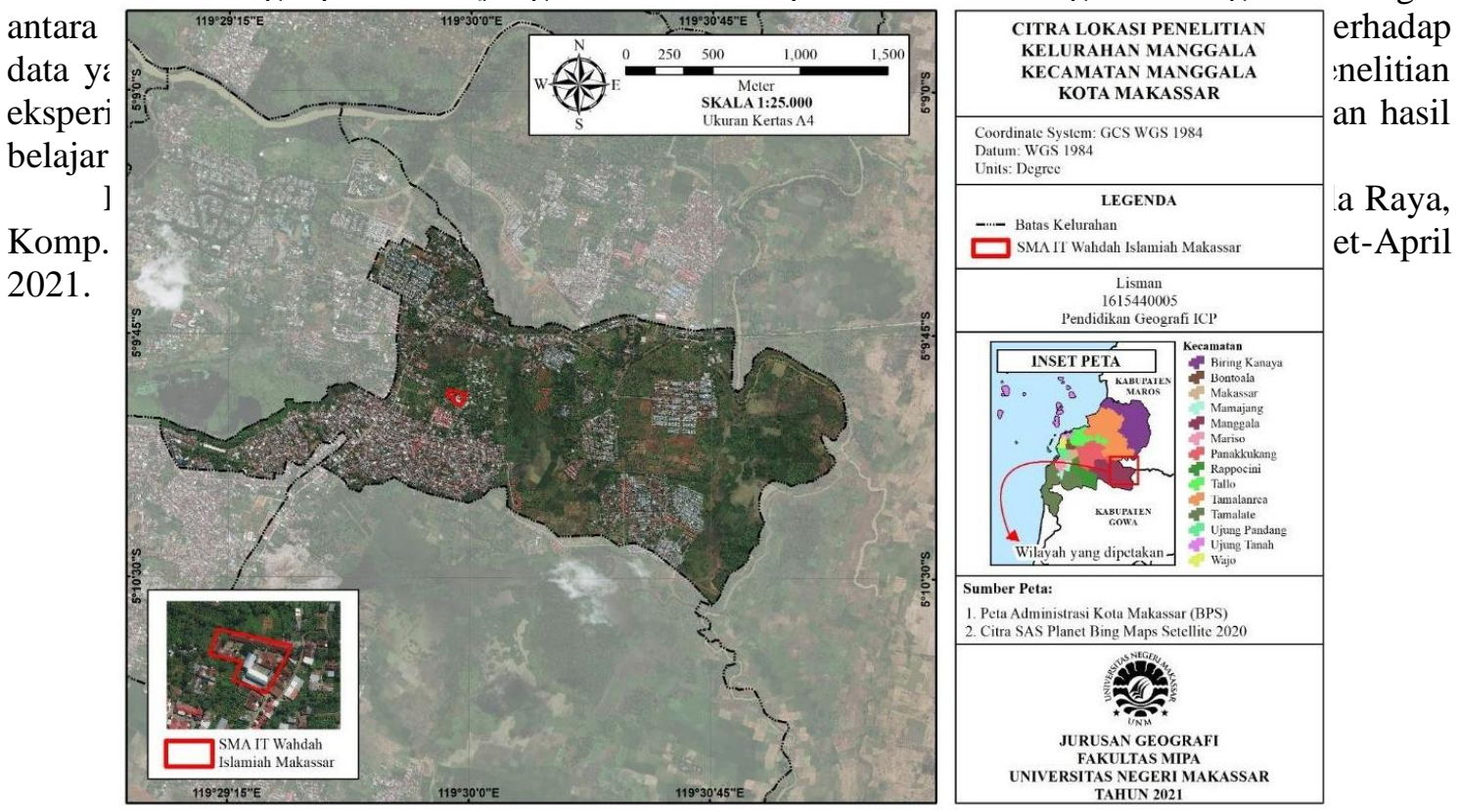

Gambar 1. Peta Lokasi Penelitian

Populasi dalam penelitian ini yakni semua peserta didik kelas XII IPS di SMA IT Wahdah Islamiyah Makassar. Berhubung kelas XII IPS di SMA IT Wahdah Islamiyah Makassar hanya memiliki satu kelas dengan jumlah peserta didik sebanyak 25 orang maka 
Ibrahim Abbas, Erman Syarif, Lisman, 2021, Hubungan Kecerdasan Emosional Dengan Hasil Belajar Geografi Siswa Kelas XII di SMA Islam Terpadu Wahdah Islamiyah Makassar

peneliti menggunakan Sampling Jenuh, menurut Sugiyono Sampling Jenuh dilakukan apabila populasi relative kecil atau kurang dari 30 orang.

Langkah-langkah yang dilakukan dalam penelitian kuantitatif korelasional ini adalah sebagai berikut :

1. Tahap Konseptual (merumuskan dan mengidentifikasi masalah, meninjau teori yang relevan, mendefinisikan kerangka teoritis, dan merumuskan hipotesis).

2. Membuat Instrumen dan pengumpulan data penelitian.

3. Fase Empirik (pengumpulan data, persiapan data untuk dianalisis) mengumpulkan data penelitian yang telah dilaksanakan dilapangan.

4. Fase Analitik (menganalisis dan menghitung hasil data penelitian), mengolah dan menganalisis data hasil penelitian. Data yang telah dikumpulkan dan lapangan diolah dan dianalisis untuk mendapatkan kesimpulan-kesimpulan yang diantaranya kesimpulan dari hasil pengujian hipotesis penelitian.

5. Fase Diseminasi, mendesain hasil penelitian. Pada tahap akhir, agar hasil penelitian dapat dibaca, dimengerti, dan diketahui oleh pembaca maka hasil penelitian disusun dalam bentuk kesimpulan dan hasil penelitian.

Teknik pengumpulan data dalam penelitian ini merupakan kuesioner. Kuesioner adalah teknik pengumpulan data yang dilakukan dengan cara seperangkat pertanyaan atau pernyataan tertulis kepada responden untuk dijawab. Teknik ini digunakan bila peneliti ingin tahu dengan pasti variabel yang akan di ukur dan atau apa yang bisa diharapkan responden (D. Sugiyono, 2013).

Pada subyek penelitian dikenakan Skala Inventori Quotient (EQ) yang telah disusun berdasarkan aspek-aspek kecerdasan emosi menurut (Salovey \& Mayer, 1990), yaitu meliputi kemampuan mengenali emosi diri, mengelola emosi, memotivasi diri sendiri, mengenali emosi orang lain, dan membina hubungan. Koefisien korelasi validitas rxy $=0,507$ dengan $p<0,05$ dan koefisien realibilitas $\mathrm{rxx}=0,878$. Kuesioner ini terdiri dari dua macam pernyataan yaitu pernyataan favourable dan unfavourable. Favourable adalah pertanyaan yang mendukung, memihak, atau menunjukkan ciri adanya atribut yang diukur. Aitem favourable sebanyak 20 pernyataan dan unfavourable sebanyak 20 pernyataan. Adapun Blue print Skala Inventori EQ adalah sebagai berikut:

Tabel 1. Indikator Skala Inventori EQ pada Kecerdasan Emosional

\begin{tabular}{llc}
\hline Jenis Aitem & \multicolumn{1}{c}{ Nomor Aitem } & Jumlah \\
\hline Favourable & $1,2,3,4,5,11,12,13,14,15,21,22,23$, & 20 \\
& $24,25,31,32,33,34,35$ & \\
Unfavourable & $6,7,8,910,16,17,18,19,20,26,27,28$, & 20 \\
& $2930,36,37,38,39,40$ & \\
\hline Total & & 40 \\
\hline
\end{tabular}


Ibrahim Abbas, Erman Syarif, Lisman, 2021, Hubungan Kecerdasan Emosional Dengan Hasil Belajar Geografi Siswa Kelas XII di SMA Islam Terpadu Wahdah Islamiyah Makassar

Dalam alat ukur ini digunakan skala: Sangat Setuju (SS), Setuju (S), Tidak Setuju (TS), dan Sangat Tidak Setuju (STS). Pemberian skor untuk tiap subjek didasarkan atas sifat pernyataan dan alternatif jawaban yang dipilih. Untuk pernyataan yang bersifat favourable adalah Sangat Setuju bernilai 4, Setuju bernilai 3, Tidak Setuju bernilai 2, dan Sangat Tidak Setuju bernilai 1. sedangkan untuk pernyataan yang bersifat unfavourable adalah Sangat Setuju bernilai 1, Setuju bernilai 2, Tidak Setuju bernilai 3, dan Sangat Tidak Setuju bernilai 4.

Teknik analisis data pada penelitian ini menggunakan analisis statistik deskriptif dan analisis inferensial. Analisis statistik deskriptif dalam penelitian ini adalah untuk melihat gambaran mengenai Hubungan Kecerdasan emosional terhadap Hasil belajar. Teknik analisis deskriptif yang digunakan dalam penelitian ini adalah melalui perhitungan rata - rata (M), median (Me), dan standar deviasi (SD). Perhitungan untuk rerata ideal dan deviasi dapat dihitung dengan acuan norma sebagai berikut :

$$
\begin{aligned}
\mathrm{Mi} & =\frac{1}{2}(S T+S R) \\
\mathrm{SDi} & =\frac{1}{6}(S T+S R)
\end{aligned}
$$

\footnotetext{
Keterangan:

$\mathrm{Mi}=$ Mean (rerataan ideal)

$\mathrm{SDi}=$ Standar Deviasi Ideal

ST $=$ Skor Ideal Tertinggi

SR $=$ Skor Ideal Terendah
}

Skor ideal tertinggi (ST) dan skor ideal terendah (SR) diperoleh berdasarkan penilaian likert (rentang skor 1 - 4), skor tertinggi 4 dan skor terendah 1 dikalikan jumlah butir pertanyaan. Hasil dari perhitungan Mid an SDi tersebut dikategorikan kecenderungan variabel Persepsi peserta didik terhadap gaya belajar sebagai berikut:
a. $\quad \mathrm{X}>\mathrm{Mi}+1,5 \mathrm{Sdi}$
b. $\mathrm{Mi}+0,5 \mathrm{Sdi}<\mathrm{X} \leq \mathrm{Mi}+1,5 \mathrm{Sdi}$
kategori sangat tinggi
c. $\mathrm{Mi}-0,5 \mathrm{Sdi}<\mathrm{X} \leq \mathrm{Mi}+1,5 \mathrm{Sdi}$
kategori tinggi
d. $\mathrm{Mi}-1,5 \mathrm{Sdi}<\mathrm{X} \leq \mathrm{Mi}-0,5 \mathrm{Sdi}$
kategori sedang
kategori rendah
e. $\mathrm{X} \leq \mathrm{Mi}-1,5 \mathrm{Sdi}$
kategori sangat rendah

Analisis inferensial digunakan untuk mengetahui hubungan kecerdasan emosional terhadap hasil belajar peserta didik kelas XII IPS 1 SMA IT Wahdah Islamiyah Makassar.

Hipotesis dalam penelitian ini adalah :

a. Ho : Tidak terdapat hubungan antara Kecerdasan Emosional terhadap hasil belajar geografi peserta didik kelas XII IPS 1 SMA IT Wahdah Islamiyah Makassar.

b. H1 : Terdapat hubungan antara Kecerdasan emosional terhadap hasil belajar geografi peserta didik kelas XII IPS 1 SMA IT Wahdah Islamiyah Makassar. 
Ibrahim Abbas, Erman Syarif, Lisman, 2021, Hubungan Kecerdasan Emosional Dengan Hasil Belajar Geografi Siswa Kelas XII di SMA Islam Terpadu Wahdah Islamiyah Makassar

\section{HASIL DAN PEMBAHASAN}

\section{Hasil}

\section{Deskripsi Data Kecerdasan Emosional (Variabel X)}

Untuk menjelaskan deskripsi penelitian ini akan dijabarkan deskripsi data berupa rentang skor, rata-rata, standar deviasi, dan modus. Adapun hasil analisis deskriptif kecerdasan emosional pada masing variabel adalah sebagai berikut:

Tabel 2. Analisis deskriptif Statistics Kecerdasan Emosional

\begin{tabular}{lc}
\hline \multicolumn{1}{c}{ Statistika } & Nilai Statiska \\
\hline Mean & 107.84 \\
Maksimum & 125 \\
Minimum & 89 \\
Banyaknya Sampel & 25 \\
Standar Deviasi & 9.978 \\
\hline
\end{tabular}

Sumber: Hasil olah data SPSS, 2021

Berdasarkan tabel hasil pengumpulan data mengenai variabel kecerdasan emosional (X) menunjukkan bahwa skor tertinggi sebesar 125, skor terendah sebesar 89, skor rata-rata terbesar 107,84, dan standar deviasi sebesar 9,978.

Tabel 3. Frekuensi Kecerdasan Emosional

\begin{tabular}{lcccc}
\hline & Frequency & Percent & Valid Percent & Cumulative Percent \\
\hline 89 & 1 & 4.0 & 4.0 & 4.0 \\
92 & 1 & 4.0 & 4.0 & 8.0 \\
96 & 1 & 4.0 & 4.0 & 12.0 \\
97 & 1 & 4.0 & 4.0 & 16.0 \\
98 & 1 & 4.0 & 4.0 & 20.0 \\
100 & 1 & 4.0 & 4.0 & 24.0 \\
103 & 2 & 8.0 & 8.0 & 32.0 \\
104 & 1 & 4.0 & 4.0 & 36.0 \\
105 & 3 & 12.0 & 12.0 & 48.0 \\
107 & 3 & 12.0 & 12.0 & 60.0 \\
110 & 1 & 4.0 & 4.0 & 64.0 \\
111 & 1 & 4.0 & 4.0 & 68.0 \\
112 & 1 & 4.0 & 4.0 & 72.0 \\
115 & 1 & 4.0 & 4.0 & 76.0 \\
118 & 2 & 8.0 & 8.0 & 84.0
\end{tabular}


email: lageografia@unm.ac.id

Jurusan Geografi Fakultas Matematika dan Ilmu Pengetahuan Alam

Universitas Negeri Makassar Sulawesi Selatan, Indonesia

Ibrahim Abbas, Erman Syarif, Lisman, 2021, Hubungan Kecerdasan Emosional Dengan Hasil Belajar Geografi Siswa Kelas XII di SMA Islam Terpadu Wahdah Islamiyah Makassar

122

8.0

8.0

92.0

Sumber: Hasil olah data SPSS, 2021

Untuk lebih jelasnya data tentang frekuensi dan persentasi variabel (X) kecerdasan emosional sebagai berikut:

Tabel 4. Indeks Tingkat Kecerdasan Emosional

\begin{tabular}{lcccc}
\hline No & $\begin{array}{c}\text { Rentang Perolehan Skor } \\
\text { Emosional Kecerdasan }\end{array}$ & $\begin{array}{c}\text { Level/Tingkat } \\
\text { Kecerdasan } \\
\text { Emosional }\end{array}$ & $\begin{array}{c}\text { Jumlah } \\
\text { Peserta } \\
\text { didik }\end{array}$ & Persentase\% \\
\hline 1. & $89-95$ & Sangat Rendah & 2 & $8 \%$ \\
2. & $96-102$ & Rendah & 4 & $16 \%$ \\
3. & $103-110$ & Sedang & 10 & $40 \%$ \\
4. & $111-118$ & Tinggi & 5 & $20 \%$ \\
5. & $119-125$ & Sangat Tinggi & 4 & $16 \%$ \\
\hline & Jumlah & & 25 & $100 \%$ \\
\hline
\end{tabular}

Sumber: Hasil olah data SPSS 2021

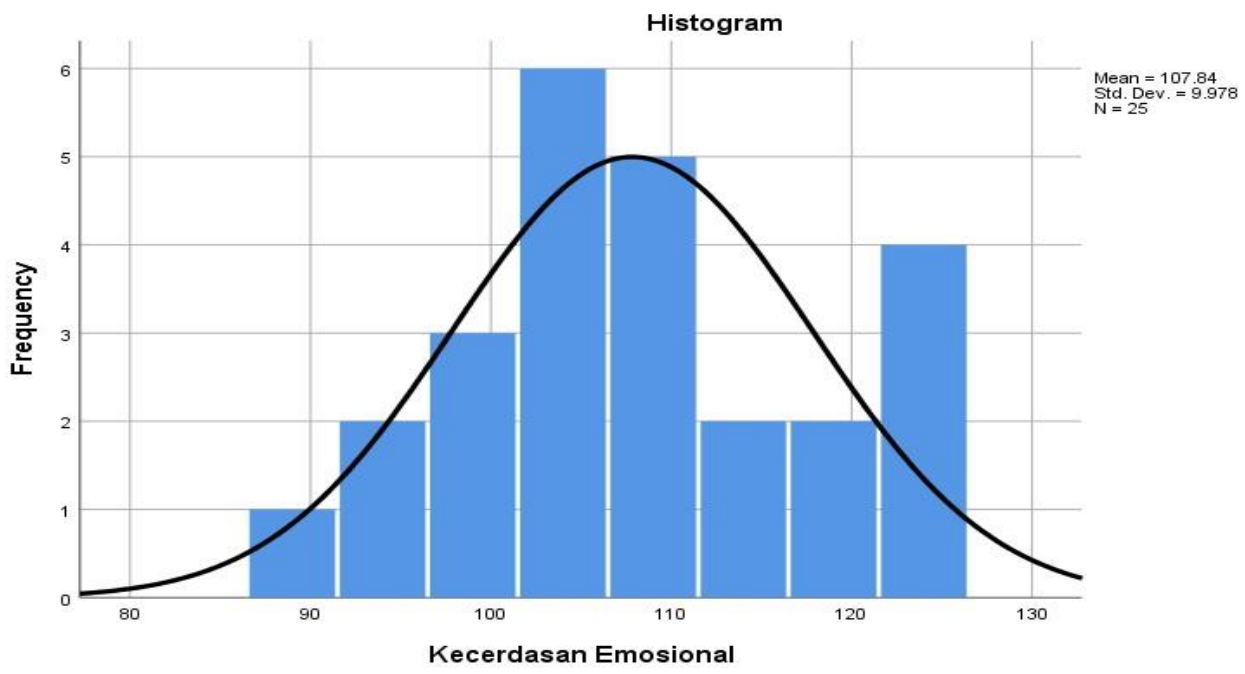

Gambar 2. Histogram Distribusi Kecerdasan Emosional

Dengan demikian dapat diinterpretasikan bahwa skor yang berada pada interval 103110 merupakan skor paling banyak yaitu sebesar $40 \%$ dan kategori kecerdasan emosional berada pada tingkat sedang. 
Ibrahim Abbas, Erman Syarif, Lisman, 2021, Hubungan Kecerdasan Emosional Dengan Hasil Belajar Geografi Siswa Kelas XII di SMA Islam Terpadu Wahdah Islamiyah Makassar

\section{Deskripsi Data Hasil Belajar Geografi (Variabel Y)}

Deskripsi data penelitian tentang hasil belajar peserta didik pada pelajaran geografi, penulis menggunakan nilai rapor pada pelajaran geografi di SMA IT Wahdah Islamiyah Makassar yaitu mencakup data mengenai jumlah responden, perolehan skor yang dilihat dari minimum, maksimum, mean, dan standar deviasi. Adapun hasil analisis deskriptif hasil belajar geografi peserta didik dapat dilihat pada tabel sebagai berikut:

Tabel 5. Analisis Deskriptif Hasil Belajar Geografi

\begin{tabular}{lc}
\hline \multicolumn{1}{c}{ Statistika } & Nilai Statiska \\
\hline Mean & 83.5200 \\
Standar Deviasi & 4.19444 \\
Minimum & 78.00 \\
Maksimum & 94.00 \\
Banyaknya Sampel & 25
\end{tabular}

Sumber: Hasil olah data SPSS, 2021

Tabel 6. Frekuensi Hasil Belajar Geografi

\begin{tabular}{cccc}
\hline & Frequency & Valid Percent \\
\hline Valid & 78.00 & 2 & 8.0 \\
& 79.00 & 5 & 20.0 \\
81.00 & 2 & 8.0 \\
82.00 & 3 & 12.0 \\
83.00 & 2 & 8.0 \\
85.00 & 1 & 4.0 \\
86.00 & 4 & 16.0 \\
87.00 & 1 & 4.0 \\
& 88.00 & 3 & 12.0 \\
89.00 & 1 & 4.0 \\
\hline
\end{tabular}

Sumber: Hasil olah data SPSS, 2021

Jika dibuatkan indeks tingkat hasil belajar geografi peserta didik sebanyak 25 orang adalah sebagai berikut: 
email: lageografia@unm.ac.id

Jurusan Geografi Fakultas Matematika dan Ilmu Pengetahuan Alam

Universitas Negeri Makassar Sulawesi Selatan, Indonesia

Ibrahim Abbas, Erman Syarif, Lisman, 2021, Hubungan Kecerdasan Emosional Dengan Hasil Belajar Geografi Siswa Kelas XII di SMA Islam Terpadu Wahdah Islamiyah Makassar

Tabel 7. Indeks Tingkat Hasil Belajar Geografi

\begin{tabular}{ccccc}
\hline No & $\begin{array}{c}\text { Rentan Perolehan Skor } \\
\text { Hasil Belajar }\end{array}$ & $\begin{array}{c}\text { Level/Tingkat Hasil } \\
\text { Belajar }\end{array}$ & $\begin{array}{c}\text { Jumlah } \\
\text { Peserta }\end{array}$ & Persentase\% \\
\hline 1. & $78-80$ & Sangat Rendah & 7 & $28 \%$ \\
2. & $81-84$ & Rendah & 7 & $28 \%$ \\
3. & $85-88$ & Sedang & 9 & $36 \%$ \\
4. & $89-91$ & Tinggi & 1 & $4 \%$ \\
5. & $92-94$ & Sangat Tinggi & 1 & $4 \%$ \\
\hline & Jumlah & & 25 & $100 \%$ \\
\hline
\end{tabular}

Sumber: Hasil olah data SPSS, 2021

Berdasarkan data perhitungan perolehan rata-rata skor hasil belajar geografi adalah sebesar 83.52 dan termasuk dalam katerogi tingkat hasilbelajar rendah. Untuk lebih memperjelas tabel 4.7 akan disajikan histogram data mengenai gambaran hasil belajar geografi.

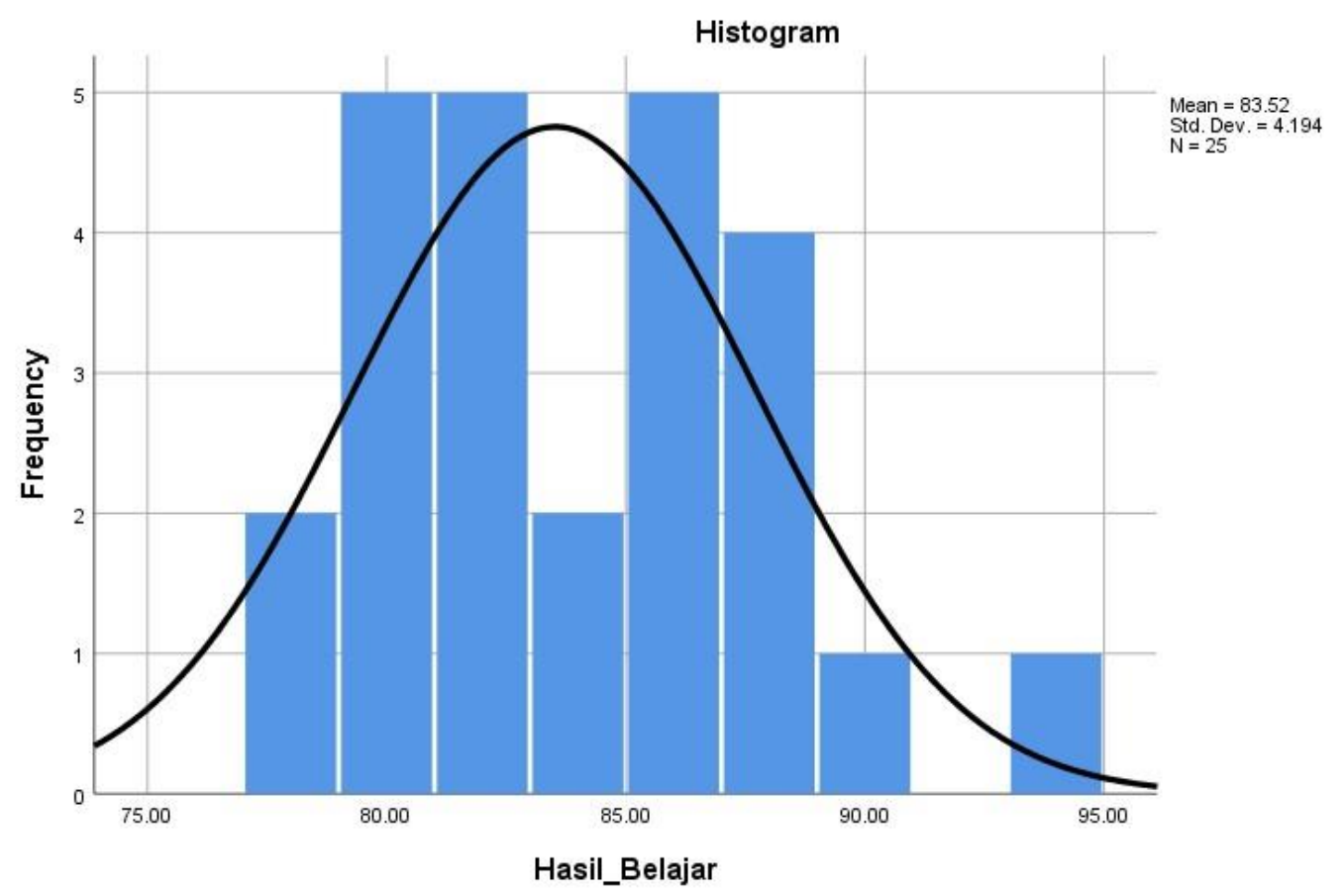

Gambar 3. Histogram Distribusi Hasil Belajar Geografi 
Ibrahim Abbas, Erman Syarif, Lisman, 2021, Hubungan Kecerdasan Emosional Dengan Hasil Belajar Geografi Siswa Kelas XII di SMA Islam Terpadu Wahdah Islamiyah Makassar

Dengan demikian dapat diinterpretasikan bahwa skor yang berada pada interval 8588 merupakan skor paling banyak yaitu sebesar $36 \%$ dan ketegori hasil belajar berada pada tingkat cukup.

\section{Uji Persyaratan Analisis dan Uji Hipotesis}

Uji persyaratan analisis dilakukan dengan tujuan untuk mengetahui data pengajuan hipotesis apakah bisa dilanjutkan atau tidak. Dalam penelitian ini peneliti menggunakan uji normalitas. Uji persyaratan analisis dalam penelitian ini menggunakan program Statistic Product and Service Solution (SPSS) 25.

a. Uji Normalitas

Uji normalitas merupakan uji awal yang dilakukan untuk menetukan apakah populasi data berdistribusi normal atau tidak, yaitu dengan membandingkan nilai signifikannya. Model regresi yang baik adalah memilki nilai residual yang berdistribusi normal. Pada penelitian ini, untuk menguji normalitas data peneliti menggunakan metode uji One Sample Kolomogrof-Smirnov. Uji normalitas Kolomogrof-Smirnov merupakan bagian dari uji asumsi klasik. Adapun dasar pengambilan keputasan sebagai berikut:

1) Jika signifikansi $<0,05$ maka $\mathrm{H} 0$ ditolak.

2) Jika signifikansi $>0,05$ maka H0 diterima.

Tabel 8. Uji normalitas One-Sample Kolmogorov-Smirnov Test

\begin{tabular}{|c|c|c|}
\hline & & Unstandardized Residual \\
\hline $\mathrm{N}$ & & 25 \\
\hline \multirow[t]{2}{*}{ Normal Parameters ${ }^{a, b}$} & Mean & 0000000 \\
\hline & Std. Deviation & 4.24221714 \\
\hline Extreme & Absolute & .131 \\
\hline \multirow[t]{2}{*}{ Differences } & Positive & .131 \\
\hline & Negative & -.120 \\
\hline Test Statistic & & .131 \\
\hline Asymp. Sig. (2-tailed) & & $.200^{\mathrm{c}, \mathrm{d}}$ \\
\hline
\end{tabular}

Sumber: Hasil olah data SPSS, 2021

Berdasarkan hasil uji normalitas diketahui bahwa nilai signifikansi 0,200>0,05, maka dapat disimpulkan bahwa nilai residual berdistribusi normal.

\section{b. Uji Hipotesis}

1) Analisis Korelasi Rank Spearman

Dalam penelitian ini, peneliti menggunakan analisis korelasi rank spearman untuk mengetahui hubungan antara dua variabel dan korelasi jumlah skor antara variabel kecerdasan emosional dengan hasil belajar. Dalam hal ini nilai korelasi rank spearman berada diantara $-1 \mathrm{~s} / \mathrm{d} 1$. Apabila nilai $=0$ maka tidak ada korelasi atau tidak ada hubungan antara variabel independen dan dependen. 
Ibrahim Abbas, Erman Syarif, Lisman, 2021, Hubungan Kecerdasan Emosional Dengan Hasil Belajar Geografi Siswa Kelas XII di SMA Islam Terpadu Wahdah Islamiyah Makassar

Apabila nilai +1 maka terdapat hubungan antara variabel independen dan dependen. Sedangkan untuk nilai $=-1$ maka terdapat hubungan negatif anatara variabel independen dan dependen, dan untuk mengetahui tingkat keeratan hubungan antara variabel kecerdasan emosional dan hasil belajar geografi digunakan pendapat (P. Sugiyono, 2019) dalam pedoman memberikan interpretasi koefisien korelasi sebagai berikut:

Tabel 9. Interpretasi Koefisien Korelasi

\begin{tabular}{c|c}
\hline Interpretasi Koefisien Korelasi & Keterangan \\
\hline $0,00-0,199$ & sangat rendah \\
\hline $0,20-0,399$ & rendah \\
\hline $0,40-0,599$ & sedang \\
\hline $0,60-0,799$ & kuat \\
\hline $0,80-1.000$ & sangat kuat \\
\hline
\end{tabular}

Sumber: Sugiyono, 2019

Untuk perhitungannya peneliti menggunakan program SPSS 25. Adapun hasil perhitungannya dapat dilihat pada table berikut:

Tabel 10. Uji Korelasi Rank Spearmen

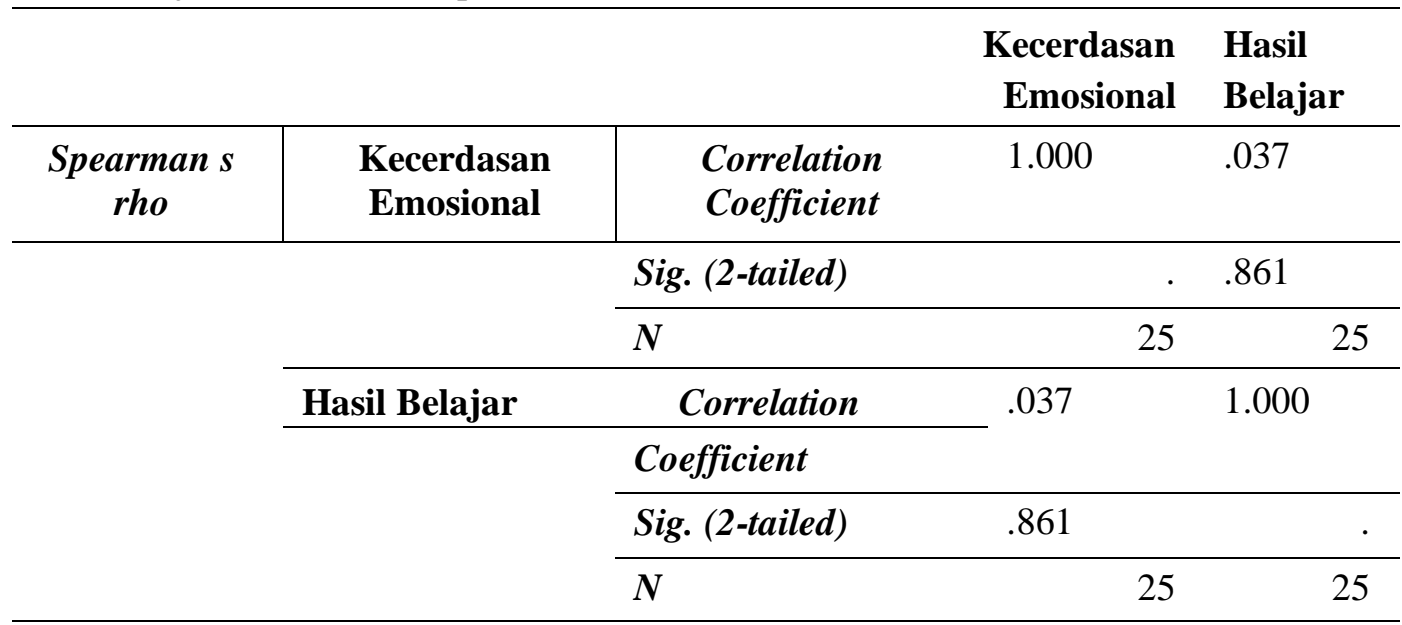

Sumber: Hasil olah data SPSS, 2021

Jadi dapat disimpulkan bahwa kecerdasan emosional dengan hasil belajar memiliki hubungan yang sangat renda, karena koefisien korelasi tidak mendekati 1 melainkan mendekati 0 maka hipotesis $\mathrm{H}_{0}$ yang menyatakan bahwa tidak terdapat hubungan yang signifikan antara kecerdsan emosional dengan hasil belajar geografi diterima. Dengan demikian hipotesis alternative $\mathrm{H}_{1}$ yang 
Ibrahim Abbas, Erman Syarif, Lisman, 2021, Hubungan Kecerdasan Emosional Dengan Hasil Belajar Geografi Siswa Kelas XII di SMA Islam Terpadu Wahdah Islamiyah Makassar

menyatakan bahwa ada hubungan yang signifikan antara kecerdasan emosional dengan hasil belajar geografi ditolak.

\section{2) Koefisien Determinasi}

Untuk mengetahui hubungan antara dua variabel independen dan dependen maka dilakukan perhitungan menggunakan Software SPSS 25. Sebagai berikut:

Tabel 11. Uji koefisien determinasi Model Summary

\begin{tabular}{lllll}
\hline Model & $\boldsymbol{R}$ & $\boldsymbol{R}$ Square & Adjusted $\boldsymbol{R}$ Square & Std. Error of Estimate \\
\hline 1 & $.030^{\mathrm{a}}$ & .001 & -.043 & 4.833 \\
\hline
\end{tabular}

Sumber: Hasil olah data SPSS, 2021

Berdasarkan Output nilai R Square adalah 0,001 dapat dikatakan bahwa $0,1 \%$. Hal ini berarti variabel kecerdasan emosional (X) memiliki kontribusi sebesar $0,1 \%$ terhadap hasil belajar geografi (Y). Hal ini menunjukkan bahwa kecerdasan emosional mempunyai hubungan yang sangat rendah dengan hasil belajar geografi dan 99,9\% dipengaruhi oleh sebab-sebab lain yang tidak disebutkan dalam penelitian ini.

Berdasarkan hasil perhitungan diatas dapat disimpulkan bahwa kecerdasan emosional mempunyai hubungan yang sangat rendag dengan hasil belajar geografi karena hanya memperoleh persentase sebesar $0,1 \%$.

\section{Pembahasan}

Berdasarkan dari hasil penelitian menunjukkan bahwa kecerdasan emosional peserta didik kelas XII di SMA IT Wahdah Islamiyah Makassar pada umumnya berada dalam kategori sedang. Hasil didapatkan dengan melihat jumlah poin yang telah dianalisis disetiap indikator kecerdasan emosional yang disebar melalui googleform. Meskipun ada beberapa peserta didik yang menunjukkan kecerdasan emosional yang cukup tinggi, namun secara keseluruhan tergolong sedang. Dengan demikian masih perlu ditingkatkan agar peserta didik memiliki kecerdasan emosional tinggi. Menurut (Uno, 2006) tinggi rendahnya kecerdasan emosional dapat disempurukan dengan kesungguhan, pelatihan dan kemauan.

Seperti yang dipaparkan Ari Ginanjar dalam bukunya yaitu kemampuan mengenali faktor-faktor yang mempengaruhi kecerdasan emosional. Caranya adalah dengan mengembalikan manusia pada fitrah hatinya atau god spot, sehingga manusia akan mampu melihat dengan mata hati, mampu melihat dengan tepat, dan memprioritaskan yang benar. Karena kecerdasan emosi meliputi unsur suara hati, kesadaran diri, motivasi, etos kerja, keyakinan, integritas, komitmen, konsistensi, presistensi, kejujuran, daya tahan dan keterbukaan.

Berdasarkan hasil penelitian yang diperoleh dari 25 responden, hasil belajar yang berada pada skor interval 85-88 merupakan skor paling banyak yaitu sebesar 36\% dan ketegori 
Ibrahim Abbas, Erman Syarif, Lisman, 2021, Hubungan Kecerdasan Emosional Dengan Hasil Belajar Geografi Siswa Kelas XII di SMA Islam Terpadu Wahdah Islamiyah Makassar

hasil belajar berada pada tingkat cukup. Hal ini menunjukkan bahwa hasil belajar geografi peserta didik cukup karena sudah mencapai nilai KKM, untuk itu perlu ditingkatkan lagi kualitas pembelajaran agar mampu meningkatkan hasil belajar.

Pada hasil penelitian (Bancin, 2017) yang melakukan penelitian tentang Hubungan Kecerdasan Emosional Dengan Hasil Belajar Geografi Peserta didik Kelas X SMA Amir Hamzah Medan didapatkan adanya hubungan yang positif atau signifikan antara kecerdasan emosional dengan hasil belajar geografi peserta didik di SMA Amir Hamzah Medan ditunjukkan dengan perolehan nilai $r=0,62$ yang termasuk kedalam kategori kuat. Hal yang menjadikan penelitianya signifikan karena faktor internal dan eksternal peserta didik mendukung dengan baik.

Namun pada hasil penelitian ini terdapat perbedaan, dimana penelitian kali ini sejalan dengan penelitian Putri Khaerunnisa Maraeni dengan judul Hubungan Kecerdasan Emosional Terhadap Hasil Belajar Akidah Akhlak peserta didik di Madrasah Aliyah Khazanah Kebajikan Pondok Cabe Tangeran Selatan. Dalam penelitiaanya didapatkan hubungan yang negatif atau tidak signifikan dengan hasil perhitungan menggunakan rumus analisis korelasi Rank Spearman dengan koefisien korelasi $=0,280$ dengan taraf signifikan $=0,114$, karena signifikansi > 0,05 maka $\mathrm{H0}$ diterima. Hal yang menjadikan penelitianya tidak signifikan karena adanya faktor internal dan eksternal peserta didik yang memberikan pengaruh selama kegiatan pembelajaran. Selain itu ia juga mengatakan bahwa sampel dalam penelitianya sebanyak 33 kurang memenuhi syarat dari jumlah populasi sebanyak 116 terbukti dengan hasil yang tidak sesuai dengan hipotesis yang diajukan.

Dari uraian di atas hasil penelitian yang telah dilakukan menunjukkan bahwa terdapat hubungan akan tetapi sangatlah rendah antara kecerdasan emosional dengan hasil belajar geografi peserta didik di SMA Islam Terpadu Wahdah Islamiyah Makassar. Setelah itu penulis melakukan analisis mengapa kecerdasan emosional sangat rendah memberikan hubungan yang signifikan terhadap hasil belajar geografi.

Menurut (Uno, 2006) berbagai penelitian telah menunjukan bahwa keterampilan EQ dapat membuat anak atau peserta didik bersemangat tinggi dalam belajar. Anak yang memiliki EQ tinggi disukai oleh teman-temannya di arena bermain, hal tersebut juga akan membantu anak tersebut dua puluh tahun kemudian, ketika dia telah memasuki dunia kerja atau ketika sudah berkeluarga. EQ memungkinkan emosi seseorang menjadi sumber yang berguna dan bahkan sumber kebijaksanaan, bukannya menjadi gangguan yang mengalihkan perhatian dan karenanya dapat meningkatkan kapasitas untuk sukses. Sedangkan penelitian yang dilakukan oleh Goleman dan Pelster bersama Characterplus memberikan informasi bahwa kecerdasan emosional sangat penting bagi kesuksesan, termasuk hasil belajar.

Dalam teori sebelumnya telah dikatakan bahwa kecerdasan emosi memiliki 5 aspek penting, yakni adalah kemampuan mengenali emosi diri, mengelola emosi diri, dan memotivasi diri. Dengan mengenali emosi, mampu mengelola emosinya serta mampu memotivasi dirinya, maka akan tercapai keseimbangan di dalam diri individu (Goleman, 2000). Sedangkan untuk 
Ibrahim Abbas, Erman Syarif, Lisman, 2021, Hubungan Kecerdasan Emosional Dengan Hasil Belajar Geografi Siswa Kelas XII di SMA Islam Terpadu Wahdah Islamiyah Makassar

faktor lainnya yaitu empati dan keterampilan sosial sangat berpengaruh dalam mengerjakan tugas kelompok, baik di dalam maupun di luar kelas. Beberapa peserta didik masih kurang memperoleh pendidikan pengenalan emosi sendiri, sehingga mereka tidak sadar akan emosi yang muncul dan tidak tahu bagaimana mengendalikan emosi serta bagaimana mengungkapkan emosi secara benar.

Guru inginkan anak-anak datang ke kelas merasa senang maka guru harus membuatnya bersemangat, jika peserta didik ingin jadi lebih baik, guru harus bisa menyentuh hatinya. Bagaimana bisa berharap peserta didik berubah, jika guru hanya memerintah dalam artian hanya memberikan yang instan kepada peserta didik, hal ini perlu menjadi perhatian karena ini tentang masa depan negara dan pendidikan suatu negara bergantung sama guru. Guru masih kurang menyadari bahwa proses belajar secara fundamental adalah proses kejiwaan yang sangat penuh dengan nuansa emosi. Dalam kondisi seperti ini, guru dalam menjalankan tugasnya tidak hanya mengembangkan aspek intelektual, tapi juga berfokus pada emosi siswa. Dengan demikian siswa akan lebih cepat bersosialisasi, mandiri dan kreatif. Kemampuan emosi seperti mengatasi suatu konflik, mengendalikan marah, berkonsentrasi, mengarahkan diri, berempati, dan keterampilan sosial cenderung tidak dilakukan penilaian, selain itu masih banyak tenaga pendidik yang belum mengaplikasikan peranan emosi terhadap suatu mata pelajaran dalam lingkup pendidikan, sehingga mereka kurang menanggapi emosi yang dialami siswa.

Faktor di atas sangat mempengaruhi secara nyata ketika materi pelajaran diberikan di kelas, sedangkan untuk faktor lainnya yaitu empati dan keterampilan sosial sangat berpengaruh dalam mengerjakan tugas kelompok, baik di dalam maupun di luar kelas. Kecerdasan emosional tidak diajarkan secara khusus di sekolah dan tidak tercatat dalam dokumen rapor, seperti nilai-nilai pelajaran ataupun keterampilan lainnya sehingga tidak ada sumbangan secara langsung terhadap peningkatan hasil belajar. Maka dengan adanya kecerdasan emosional ketika seseorang belajar geografi mampu memotivasi dirinya bahwa geogarfi bukan hal yang membosankan, tetapi merupakan awal keberhasilan untuk mencapai hasil belajar yang lebih baik, seseorang yang mampu memotivasi diri akan mampu mempertahankan semangat hidup, untuk selalu optimis terhadap sesuatu hal sehingga berkorelasi positif dengan keberhasilan akademis, sosial, dan kesehatan mentalnya.

Peserta didik yang memiliki kecerdasan emosi tinggi identik dengan anak yang bahagia, bermotivasi tinggi, dan mampu bertahan dalam menjalani berbagai kondisi stres yang dihadapi. Dengan kecerdasan emosional diharapkan peserta didik memiliki kemampuan mengatasi rasa jenuh dalam belajar, putus asa, tidak senang, gagal, serta setiap perasan negative yang muncul. Peranan kecerdasan emosi yang masih dalam kategori sedang terhadap hasil belajar disebabkan oleh banyaknya faktor lain yang mempengaruhi hasil belajar itu sendiri seperti motivasi, faktor keluarga, dan faktor lingkungan. Dengan kecerdasan emosional ini, diharapkan ketika peserta didik belajar geografi mampu memotivasi dirinya bahwa geografi bukanlah hal yang sulit dan membosankan untuk dipelajari, tetapi merupakan awal dalam 
Ibrahim Abbas, Erman Syarif, Lisman, 2021, Hubungan Kecerdasan Emosional Dengan Hasil Belajar Geografi Siswa Kelas XII di SMA Islam Terpadu Wahdah Islamiyah Makassar

memahami bahwa geografi merupakan pelajaran yang membuat kita sadar bahwa bumi juga ingin dimengerti bahwasanya geografi itu sangat erat kaitanya dengan kehidupan. Hal tersebut juga dingkap oleh (Pratiwi et al., 2021) bahwa pelajaran geografi membuat peserta didik menguasai banyaknya materi pembelajaran dari berbagai fenomena keruangan ditambah dengan adanya materi yang sulit untuk dipahami tanpa melihat langsung fenomena secara nyata di lapangan.

Kecerdasan emosional yang baik haruslah dimiliki oleh peserta didik. Hal tersebut perlu menjadi perhatian karena faktor-faktor yang mempengaruhi belajar adalah kondisi internal dan eksternal peserta didik. Kondisi internal mencakup kondisi fisik, seperti kesehatan organ tubuh, kondisi psikis, seperti kemampuan intelektual, emosional, dan kondisi sosial, seperti kemampuan bersosialisai dengan lingkungan (Rifa, n.d.). Kecerdasan emosional merupakan salah satu faktor yang penting yang seharusnya dimiliki oleh peserta didik yang memiliki kebutuhan untuk meraih hasil belajar yang lebih baik di sekolah. Jadi pada penelitian ini kecerdasan emosional memiliki kontribusi $0,1 \%$ terhadap hasil belajar sedangkan 99,9\% dipengaruhi oleh sebab-sebab lain.

\section{SIMPULAN DAN SARAN}

\section{Simpulan}

Berdasarkan hasil analisis dan pembahasan yang diuraikan pada bab sebelumnya mengenai korelasi kecerdasan emosional dan terhadap hasil belajar, maka dapat disimpulkan bahwa kecerdasan emosional (EQ) pada peserta didik kelas XII IIS SMA Islam Terpadu Wahdah Islamiyah Makassar dengan jumlah 25 orang peserta didik menunjukkan bahwa data kecerdasan emosional memiliki nilai rata-rata $=107,84$ dan standar deviasi $=9,978$ dengan persentase tertinggi 40\% pada rentang skor 103-110 dengan jumlah peserta didik 10 orang. Sedangkan hasil penelitian yang diperoleh dari 25 responden pada hasil belajar terlihat bahwa skor yang berada pada interval 85-88 merupakan skor paling banyak yaitu sebesar 36\% dan ketegori hasil belajar berada pada tingkat cukup.

Berdasarkan hasil perhitungan menggunakan rumus analisis korelasi Rank Spearman maka diperoleh koefisien korelasi antara variabel kecerdasan emosional dengan hasil belajar geografi peserta didik sebesar 0,037 dengan signifikansi 0,861 (sig>0,005), maka hipotesis $\mathrm{H}_{0}$ diterima. Dengan demikian dapat ditarik kesimpulan bahwa tidak terdapat hubungan yang signifikan antara kecerdasan emosional terhadap hasil belajar geografi peserta didik kelas XII di SMA Islam Terpadu Wahdah Islamiyah Makassar.

\section{Saran}

Sehubungan dengan hasil dan pembahasan pada penelitian ini maka peneliti menyarankan untuk sekolah terutama guru-guru pengajar agar terus membina dan meningkatkan kecerdasan emosional peserta didik baik dalam proses pembelajaran di kelas maupun di kegiatan lainnya. Hal tersebut perlu menjadi perhatian karena faktor-faktor yang mempengaruhi belajar adalah 
Ibrahim Abbas, Erman Syarif, Lisman, 2021, Hubungan Kecerdasan Emosional Dengan Hasil Belajar Geografi Siswa Kelas XII di SMA Islam Terpadu Wahdah Islamiyah Makassar

kondisi internal dan eksternal peserta didik. Dan untuk peneliti selanjutnya yang tertarik dengan penelitian hubungan kecerdasan emosional terhadap hasil belajar peserta didik agar lebih memperhatikan teknik sampling yang akan digunakan terutama dalam penentuan ukuran sampel penelitian karena hal tersebut dapat menyebabkan kesalahan dalam pengambilan sebuah keputusan.

\section{DAFTAR RUJUKAN}

Ahmadi, A. (2019). Psikologi sosial.

Arikunto, S. (2019). Prosedur penelitian.

Bancin, N. H. (2017). HUBUNGAN KECERDASAN EMOSIONAL DENGAN HASIL BELAJAR GEOGRAFI SISWA KELAS X SMA AMIR HAMZAH MEDAN TAHUN AJARAN 2016/2017. UNIMED.

Bariyyah, K., \& Latifah, L. (2019). Kecerdasan Emosi Siswa Ditinjau dari Jenis Kelamin dan Jenjang Kelas. JPGI (Jurnal Penelitian Guru Indonesia), 4(2), 68-75.

Duhita, S. A., Suprapta, S., \& Hasriyanti, H. (2020). Problematika Guru dalam Pelaksanaan Kurikulum 2013 pada Pembelajaran Geografi. LaGeografia, 18(2), 109-116.

Goleman, D. (2000). Kecerdasan emosional. Gramedia Pustaka Utama.

Hamalik, O. (2007). Proses Belajar Mengajar, cet. 6. Jakarta: Bumi Aksara.

Hasriyanti, H. (2019). Pengaruh Model Pembelajaran Cooperative Integrated Reading And Composition (Circ) Terhadap Hasil Belajar Siswa Sekolah Menengah Atas. LaGeografia, 18(1), 36. https://doi.org/10.35580/lga.v18i1.10974

Ibrahim, R. (2015). Pendidikan Multikultural: Pengertian, Prinsip, dan Relevansinya dengan Tujuan Pendidikan Islam. Addin, 7(1).

Indriawati, P. (2018). Pengaruh kepercayaan diri dan kecerdasan emosional terhadap hasil belajar mahasiswa Universitas Balikpapan. Jurnal Pendidikan Edutama, 5(2), 1-10.

Khalijah, S., Suprapta, S., \& Abbas, I. (2021). Hubungan Perhatian Orang Tua terhadap Hasil Belajar Peserta Didik pada Pembelajaran Geografi. LaGeografia, 19(3), 401-416.

Nizar, S. (2002). Filsafat Pendidikan Islam: Pendekatan Historis, Teoritis dan Praktis. Ciputat Pers.

Nurjannah, H., Saputro, A., Maddatuang, M., \& Fikri, M. J. N. (2020). Penerapan Model Pembelajaran Treffinger Pada Pembelajaran Geografi. LaGeografia, 19(1), 113-127.

Nyompa, S., Suprapta, S., Wahyuni, S., \& Azhim, M. I. (2018). The Effect of Student Perception of Teacher Professional Competency On The Result of Geography Learning Class XI Social Science Student's SMA 12 Sinjai. UNM Geographic Journal, 1(2), 131136.

Pratiwi, P., Zhiddiq, S., Umar, R., \& Saputro, A. (2021). Peningkatan Hasil Belajar Siswa Pada Pembelajaran Geografi Melalui Model Discovery Learning. LaGeografia, 19(2), 226-242.

Rifa, I. (n.d.). Achmad dan Catharina Tri Anni. 2012. Psikologi Pendidikan.

Sagala, S. (2010). Supervisi Pembelajaran dalam profesi pendidikan. Bandung: Alfabeta.

Salovey, P., \& Mayer, J. D. (1990). Emotional intelligence. Imagination, Cognition and Personality, 9(3), 185-211.

Sudjana, N. (2010). Belajar dan Faktor-faktor yang Mempengaruhinya. Jakarta: Rineka Cipta. Sugiyono, D. (2013). Metode penelitian pendidikan pendekatan kuantitatif, kualitatif dan R\&D. 
email: lageografia@unm.ac.id

Jurusan Geografi Fakultas Matematika dan Ilmu Pengetahuan Alam

Universitas Negeri Makassar Sulawesi Selatan, Indonesia

Ibrahim Abbas, Erman Syarif, Lisman, 2021, Hubungan Kecerdasan Emosional Dengan Hasil Belajar Geografi Siswa Kelas XII di SMA Islam Terpadu Wahdah Islamiyah Makassar

Sugiyono, P. (2019). Metode Penelitian Pendidikan (Kuantitatif, Kualitatif, Kombinasi, $R \& D$ dan Penelitian Pendidikan) (A. Nuryanto (ed.); Ke-3). Alfabeta.

Syarif, E., Syamsunardi, S., \& Saputro, A. (2020). Implementation of Discovery Learning to Improve Scientific and Cognitive Attitude of Students. Journal of Educational Science and Technology (EST), 6(1), 23-31.

Uno, H. B. (2006). Orientasi baru dalam psikologi penbelajaran. 